\title{
Wage Digitization in Readymade Garment (RMG) Sector in Bangladesh is Crucial for Women Empowerment, Social Compliance and Competitiveness
}

\author{
Mohammad Hasan \\ Executive Director, Babylon Group, Dhaka, BANGLADESH \\ Corresponding Contact: \\ Email: mohammadhasanbg@gmail.com
}

\begin{abstract}
Bangladesh has succeeded in achieving Millennium Development Goal (MDG) set by United Nations Development Program (UNDP), where Readymade Garment (RMG) sector has played an active role. As the highest contributor in export and formal sector employment RMG sector can claim its position at the top in, out of eight goals of millennium development, eradicating extreme poverty, achieving universal primary education, ensuring gender equality and women empowerment. Bangladesh is moving from least developed country to middleincome country. Bangladesh is on its way to achieving Sustainable Development Goal (SDG) set UNDP, where 17 areas have been targeted to fulfill. The government of Bangladesh has declared its vision 2021 and BGMEA, (Bangladesh Garment Manufacturers and Exporters Association) apex body of the industry has set a target of $\$ 50 \mathrm{ml}$ export within that timeframe. To fulfill all those targets RMG has to play an important role. Though Bangladesh is in the second position regarding value, after China, in global apparel export, yet the difference between first and second is huge. Bangladesh's RMG sector is far behind in efficiency and productivity levels compared to its competing countries. Bangladesh's RMG is still highly dependent on low waged machine operators mainly females. The government has been working toward digitalization, and the sector is accommodating technology as without enhancement of a comparative and competitive advantage of this very sector, RMG, it is not possible to achieve the dreams of the apex body as well as of the government. Digitization of wage can help to ensure transparency, loss of working hours, implement compliance and women empowerment.
\end{abstract}

Key words

Wage digitization, RMG, women empowerment, Bangladesh, social compliance, social competitiveness 


\section{INTRODUCTION}

At present, in Bangladesh, Readymade Garment (RMG) is the single highest sources in the formal sector employment for women. Apart from that, the contribution of RMG is multidimensional and very significant in Bangladesh economy and international relations. Once, the aid-dependent economy has been moving towards export-oriented one. On the other hand, employment of women in the formal sector like RMG is being considered as one of the important elements of women empowerment. Economically self-reliance is the most crucial to participate in decision-making process that ultimately leads to empowerment. It is believed that female employees who constitute around eighty percent of total employment in RMG sector now can uphold their voices in family and personal matters. From the very beginning of the RMG manufacturing industry, major noncompliance issues were on wages, which has been claiming as very minimum, irregular and exploitative. All the times and all over the world RMG offers lower wages compared to other sectors. Not only the low wage, the mode of payment, cash transaction, is also helping to exploit and deprive the workers of getting actual and on time payment. The sector has experienced many unexpected incidents like workers' unrests mostly on wage issues. With a single initiative, digital transaction, the sector can resolve multiple problems like lack of transparency, repeated numbers of social audits, workers' dissatisfaction. Moreover, digitization of payment can ensure workers, especially women, empowerment and increase competitiveness among its competing countries. Here wage digitization depicts workers' attendance and working hours are recorded through electronic devices. Their wages and all others payment transaction is made through bank channel instead of cash disbursement.

The present case study focuses on how the wage digitization can ensure Women Empowerment, Social compliance and increase Competitiveness of the RMG sector in Bangladesh.

\section{ObJectives of the Research}

There are some specific objectives of the study. Among them some important areas are as follows:

- To know the current practices of wage disbursement

- To find out the difficulties with the existing payment system.

- To check the possibility of inclusion of digital payment system in RMG Sector in Bangladesh.

- To analyze the impact of digital payment system on women workers, compliance and on the industry as a whole.

\section{Research Methodology}

This is an action research based on firsthand data and information. Qualitative research methods were chosen. Data from secondary sources were also collected. An exploratory, participatory and in-depth interview was conducted with a smaller, but focused, number of the employees and female workers. Out of 9200 workforces in three factories total thirty female workers and five others like factory head, Accounts manager, Welfare officer, Participatory Committee members, Human Resources in-charge were randomly selected for the study. 


\section{BACKGROUND OF THE STUDY}

The readymade garment manufacturing industry in Bangladesh has been playing a vital role in the economic development of Bangladesh. Bangladesh is the 2ndlargest apparel exporter, next to China only, in the world. RMG is the biggest formal sector of employment in Bangladesh and is considered the backbone of the economy. Two thirds of country's labor force (approximately 4 million) is engaged in this sector, of which almost $80 \%$ are women. Unmarried girls are becoming self- reliant; additionally they are helping their families. When women participate in income generating activities, they naturally make a position in their families. Other members of the family value their decisions. They enjoy a better status and freedom compare to unemployed one and enjoy an equitable access to all family affairs. So, having an employment, the females are empowered and can participate in the decision making process in their families and societies. Presently Bangladesh holds 7th position in the world in women empowerment (BKMEA 2014).The RMG sector has given them a formal platform to be self-reliant and freedom of participation.

Table 1: Women participation in work among SAARC countries

\begin{tabular}{|c|c|c|}
\hline Country & Number of Worker & \% Women \\
\hline Bangladesh & $14,00,000$ & 90 \\
\hline Sri-Lanka & 312,00 & 81 \\
\hline India & $53,00,000$ & 38 \\
\hline Nepal & 52,000 & 18 \\
\hline Pakistan & 912,000 & 15 \\
\hline
\end{tabular}

Source: BKMEA, 2014

Bangladesh is at top position in women participation in work among the SAARC (South Asian Association for Regional Cooperation) countries. Interestingly, literacy rate in Bangladesh is behind from Sri-Lanka, Maldives, India and Nepal. Bangladesh is at top position in women employment due to the RMG sector.

This sector has the multidimensional impact on poverty alleviation through the employment generation for the poor section of the people. Out of total employment, around 4.5 million workers, more than $80 \%$ is female. The girls and the women, once had the choice of non- formal agricultural field or as maid in the rich men's houses, are now the part of main contributors in foreign currency earnings.

Social compliance is one of the most important features in export oriented RMG sector. There are specific legal guidelines in Bangladesh Labor Act (BLA -2006) regarding working hours, weekly holidays, minimum wages etc. Low productivity and less efficiency, short lead time, weak supply chain, high Non Productive Time (NPT), absenteeism, migration, short retention of the workers etc. are among the major hurdles of the sector. On the other hand, Minimum wage, Extra Over Time (EOT), holiday works, wage deduction, late and less payment are the common non-compliance areas of the sector. Over the periods, RMG sector in Bangladesh has passed through many turmoil, mostly on wage and the payment grounds. There are some important areas needed to be addressed properly and urgently. One, most importantly, of them is wage disbursement.

Traditional cash disbursement can be replaced by digital or mobile banking. With this replacement both employers and employees especially female workers can achieve another attribute towards their empowerment, number of compliance audits can be reduced ensuring transparency in payment system and finally more productivity can be achieved saving time and manpower on wage distribution processes. 


\section{Current Practices of Wage Disbursement}

Based on legal requirement and buyers code of conduct there are strict restrictions of working hours and holiday works. Due to shorter lead time and weak supply chain or delayed raw materials or production approval, disrupted utility supplies or any unpredicted reason factory has to work beyond the working hours' limit. To avoid compliance audit findings factory keeps both manual and digital attendance record of its workers. Sometimes they make double payment sheets, one for payment and other to face the audit. With those practices there are possibilities to deprive the workers from actual payment or late payment. Both, late or less payment, are gross violation of law i.e. noncompliance which create dissatisfaction among the workers and finally industry face unrest. Moreover, to carry huge amount of cash from bank is always a risk. Moreover, counting those piled up cash and disbursement of wages among the workers keep busy a section of people for a (first) week of every month.

\section{Introducing Digital Payment System using Mobile Banking in Babylon}

Mobile phone and Mobile Banking are not a luxury, rather it is now a basic need for the working women. Due to price \& complexity this basic need, mobile phone, became luxury. Now the price \& opening a bank account are very much affordable to the workers. Moreover, over the last few years wags also has been increased, workers' mindset has been changed. They are more aware of their rights- good or bad. Though they have lack of formal education but they have basic knowledge to operate mobile. According to the Bangladesh Bank data, the total registered mobile banking accounts reached $41 \mathrm{~m}$ at the end of December 2016 which was 31.8m in the December 2015 and it was only $25.1 \mathrm{~m}$ at the end of 2014. In the year 2017, till May, a total of 52.6 m users were registered. At present, a total of 17 of 19 banks that got permission to run Mobile Banking Service (MFS) operation are providing services. Of them, BRAC Bank's bKash and Dutch Bangla Bank's Rocket topped the list of service providers (Dhaka Tribune, 2016 \& 2017).

\section{FINDINGS OF THE STUDY}

\section{It's a Pride and a Strong Tools of Empowerment}

The mobile banking account is an individual and permanent nature of bank account. If any worker changes his/her job can continue the same account as, he/she wishes. This account is valid even after retirement from the job. The workers enjoy and feel proud to be a bank account holder. They are happy for getting an opportunity to save their hard earned money. This account can be used to remit foreign currency by their husbands and relatives. Married females' workers usually had to handover their salary to their husband while unmarried female workers generally send and deposit their money to their parents. Most of the cases, their parents spend their daughter's money at their will or as necessity. At the time of their marriage, they again take loan or seek help of others. But by the virtue of the digital payment system workers can save their money for their future.

Though the workers are having low level of formal education yet, they are very quick learners. It was learned from the field data that from the 2ndmonth of mobile banking transaction no mobile booth was required at factory premises to train the workers on operation system. It shows that only in onetime transaction all of them were in a position to withdraw their wages without any supervision of factory management. 


\section{A Hard and Complicated Work is Getting done Easily and Free of Cost}

Opening a bank account is one of the tough jobs in Bangladesh, especially for the poor female workers. If anyone is interested to open a bank account, he or she has to produces a list of papers with attestation by a first class government officer. The interested person needs to visit to a bank personally. Contrary, mobile bank officials visit personally to the factories where factory management provides all necessary documents. Workers only need to sign the papers where necessary. It is a zero balance account facility where no additional charges are imposed to maintain the account.

\section{Bank Transactions Minimize the Risk of Cash Carry}

To disburse wages in cash factory has to withdraw huge amount of money from bank and has to carry it to factory at least three working days before, exceptions are there, the payment day. There are risks of carrying from the bank to factory and storing those huge amount of money at factory premises. It is not very uncommon where whole money gets snatched by the miscreants, the factory officials get injured or sometimes loss their lives. At least one incident happens in every month. On the other hand, the risks of the workers of being robbed on the way to their home on wage payment day. Mobile banking reduces the risk of cash carrying, depositing and distributing.

\section{Avoid Unnecessary Compensation}

The people or departments engaged for withdrawal and disbursement wages have to take responsibility if there is any mismatch from anywhere. Depending on factory size or number of employees a team basically from Human Resources (HR) department is engaged to disburse the wages to the workers. Many of them have to pay penalty as they can't do the job as like the professional accounts people. When anyone gets less, he or she complains and the distributor has to compensate. In digital wage system manual counting and distribution do not exist. Concerned department, usually HR, sends the payment summary sheet to the bank and the bank transfers wages to the workers individual account number.

\section{Saves Money and Time}

In traditional payment system the people from Administration, Human Resources, Accounts departments work on counting, carrying, packing and distributing wages of the employees and workers. They work three to five consecutive days in every month to execute wage payment hampering their day to day works. On the contrary, it takes at least 15minute time for every worker to collect, count the wage and to go back to work. If there are five thousand workers in a factory, at least three working days are required for fifteen employees of whom average salary is TK 20,000 per month. It costs to factory TK 34,615.

Table 2: Financial impact on wage digitization

\begin{tabular}{|c|c|c|}
\hline Areas & Savings/Month & Remarks \\
\hline $\begin{array}{c}\text { Salary Count } \\
\text { (Man } 15 \times 3 \text { days) }\end{array}$ & TK34,615.00 & $\begin{array}{c}\text { Average salary TK 20,000 per month. } \\
(2000 / 26 \times 3 \times 15)\end{array}$ \\
\hline $\begin{array}{c}\text { Salary Disbursement } \\
\text { (Man } 15 \times 1 \text { day) }\end{array}$ & TK 11,538.00 & $\begin{array}{c}\text { Average salary TK } 20,000 \text { per month. } \\
(2000 / 26 \times 1 \times 15)\end{array}$ \\
\hline $\begin{array}{c}\text { Salary Collection } \\
\text { (Workers5000 } 15 \mathrm{Min})\end{array}$ & TK51,082.00 & $\begin{array}{c}\text { Avr. Wage } 8,500 \text { per month } \\
(8500 / 26 / 8 / 60 \times 15=10.22 \times 5000)\end{array}$ \\
\hline Stamp Charges & TK50,000.00 & $5000 \times$ TK 10 \\
\hline Productivity & TK5,39,136.00 & $\begin{array}{c}12,000,00 / 26=46153 \times 10 \%=4616 \mathrm{pcs} / 384 \mathrm{dz} \times \mathrm{CM} \$ 18 / \mathrm{dz} \\
=\$ 6912 \times 78\end{array}$ \\
\hline Forced Savings & TK 1610 Million & TK $350 \times 4.6 \mathrm{ml}$ \\
\hline
\end{tabular}


On the day of wage disbursement, fifteen employees get involved for whole day. In terms of money, it is TK 11,538 . To collect wages every worker needs to spend at least fifteen minutes collect and count cash, put signature and finally go back to his/her desk. If the workers average take home amount is TK 8500.00 then it comes TK 51,082.00 in a month. On the day of wage disbursement factory produces at least $10 \%$ less quantity than other working days. In terms of monetary value that ten percent stands TK $(1200,000 / 26=46153 \times 10 \%=4616 \mathrm{pcs}=384 / \mathrm{dz}$. If the CM (cutting and making charge) is $\$$ $18 / \mathrm{dz}$ then it comes (384 dz x \$ 18) \$ 6912 or TK 5, 39, 136. 00.

\section{It's a Forced Saving Instrument for the Employees}

As workers are getting their salary at bank, it creates an opportunity to save some amount at their bank account. Besides they can't take out the amount less than five hundred. If anyone gets TK 8,350 he/she can withdraw up to TK 8000 through ATM (Automated Teller Machine) both. This restriction eventually helps to keep some amount in his/her account. Considering a minimum of TK 350 saving per month a worker can saves TK 4200 in a year. Taking 15-year average service length, it stands TK 63000 at the time of job separation. The amount becomes huge if we consider this for 4.6 million workers who are serving the industry now. And the amount stands around 1610 million per month.

\section{POLICY IMPLICATIONS}

\section{Ensure Transparency and can Reduce Repeated Social Audits}

With digital payment system anyone can check his/her receivable amount. This system ensures social compliance as there is no chances of making double salary sheets, deprivation, and unlawful deduction. It is easy to find out excessive working hours and delayed payment etc.

\section{Reduce Financial Inclusion GAP}

Introducing digital system from cash payment for the largest sector like RMG narrow down the financial inclusion gap for millions of low-income groups. This initiative also ensures equal access to banking system for highly paid executives and low paid workers - male and female. With this transformation, women are more empowered by increasing their access and control over their income that can ensure strong role in decision making process of their families. Moreover, government can have more revenue from the system.

\section{Weakness of the System}

Though there are many advantages of digital payment system like ensure transparency, save time and money, increases productivity, reduce compliance audits yet there are still some weaknesses.

\section{Insufficient Number of ATM Booth}

Banking facilities in all industrial areas, especially number of ATM booths, are not sufficient compare to workers' density. The workers found that ATM server was down, no cash, cards were locked etc. A worker has to visit ATM booth more than one times to collect his/her money.

\section{Limitations of the Workers}

It is known that some of the workers forget their PIN number which is a unique security code for every individual. Some of them have no registered mobile SIM by themselves. Some of them lost their mobiles. In few cases, it was found that their accounts were hacked by their colleagues. The total amount of money was taken by their husbands. 


\section{RECOMMENDATIONS}

With a single initiative, digital transaction, the sector can resolve multiple problems like lack of transparency, repeated numbers of social audits, workers' dissatisfaction. Banks need to ensure stronger network so that workers can withdraw their money at their "first going" to the ATM booth. More banks should come forward with this facility so that workers can use any bank's booth without cost. Both the government and the buyers need to encourage digital payment system declaring various incentives. In return this system will attract more remittance through bank channel and can earn more revenue and the buyers can save audit fees. Finally, apex bodies, buyers and governments' concerned authorities can monitor the state of compliance with this payment system.

\section{Concluding Remarks}

Bangladesh Readymade garment (RMG) sector has fulfilled most of the requirements of social compliance. The sector is now working on environment issues, green production, carbon foot print, LEED certification and engaged in different CSR activities. But a few numbers of factories are paying workers' wages through electronic system i.e. through banking channel. If one can make them aware of the system and its positive impact in business, according to the study, none of the factory would continue traditional payment method. In digital system there is no wastage of time on account of wage distribution. With the saved money factory can contribute in welfare activities for the workers and the society. Digitization of wage decreases over time work for which factory has to pay at double rate. On the other hand, mobile banking saves workers personal time significantly to deposit or transfer their money to their families and increase competitiveness among its competing countries. Digital wage system is a win-win situation for all concerned - workers, entrepreneurs and the buyers. It's a Joy of dignity and Empowerment.

\section{REFERENCES}

Ahmed, N., Nasima, M., \& Alam, N. (2013). Socio-Business Consideration of Garment Workers in Bangladesh: A Statistical Review. ABC Journal of Advanced Research, 2(2), 83-92.

Aktar, M. (2014). Green Insights of Textile Industry in Bangladesh: A Case Study on Mozart Knitting Ltd.. Global Disclosure of Economics and Business, 3(1), 93-108.

BGMEA (2014-2015). Members' Directory, Bangladesh Garment Manufacturers and Exporters Association, Dhaka.

BKMEA (2014).Knit Barta: A three monthly publication of BKMEA. vol02, Description of Bangladesh Apparel Export pp 52-53, Bangladesh Knitwear Manufacturers and Exporters Association: Dhaka.

Chowdhury, M., Begum, M., Reza, M., \& Jannath, T. (2013). Micro Credit and Women Empowerment: A Study on Grameen Bank's Strategy of Poverty Alleviation. Global Disclosure of Economics and Business, 2(2), 209-224.

Chowdhury, S. (2015). The Necessities of HR practices in RMG Sector of Bangladesh. Global Disclosure of Economics and Business, 4(1), 7-20.

Chowdhury, S., \& Rahman, M. (2014). The Potentiality of Women Entrepreneurs in Bangladesh with Special Reference to Sylhet Region. Global Disclosure of Economics and Business, 3(2), 121-130.

Dhaka Tribune, 02 July 2017, over 30m mobile banking accounts inactive, Business Desk. Shariful Islam, Dhaka.

Dhaka Tribune, 25 January 2017, Mobile bank users now over 40m, Tribune Business Desk. Dhaka.

Hossain, T., \& Shirazi, H. (2018). Quality of Work Life among Women Employees Working in RMG Sector of Bangladesh. Global Disclosure of Economics and Business, 7(1), 27-40. 
Masoom, M. (2017). The Control of Externality among the Street Children and Marginalized People of Dhaka City: A Key Indicator to Ensure Sustainable Livelihood. Asian Journal of Humanity, Art and Literature, 4(1), 17-24.

Tania, F., \& Sultana, N. (2014). Health Hazards of Garments Sector in Bangladesh: The Case Studies of Rana Plaza.Malaysian Journal of Medical and Biological Research, 1(3), 113-120.

$--0-$

ISSN: 2409-3629

Online Archive Link: https://abc.us.org/ojs/index.php/ei/issue/archive 